\title{
The Consolidation of Democratic Stability under the Continuity of the Legal System Reform
}

\author{
Dr Lorenc Danaj \\ Department of Law" University of Vlore, Albania \\ Email: Iorenc.danaj@gmail.com \\ Prof. Dr. Vjollca Hasani \\ Dean of Economy Faculty, AAB University, Pristine, Kosovo \\ Dr Evis Çelo \\ Language and Management Department" University of Vlore, Albania \\ Email: evis.celo8@gmail.com \\ Prof. Dr. Alba Dumi \\ Dean of Graduated School "Ismail Qemali" University of Vlore \\ Email: alba.besi12 @gmail.com
}

Doi:10.5901/ajis.2015.v4n1p291

\begin{abstract}
During the last fifty years, the contribution of the European Council was to achieve this prospectus as the one to promote democracy, the rule of law and protection of Human Rights. In its effort Albania responded really much to the changes occurring both within Albania and Europe too. After major changes in Central and Eastern Europe, the Council of Europe has played a primary role for countries that required adaptation to democratic life and simultaneously respect for Human Rights. But the development and consolidation of democratic stability occupied primary role and certainly had a substantial costs on people. In 1925 the Resident Chamber of International Justice which in its advisory opinion states: " a state that has undertaken so valuable international obligations is bound to make its legislation necessary changes to ensure the execution of accepted commitments " 1 So up to where and to what extent the Republic of Albania has respected the following principles of law that except to opinions of instances of international law, on the other hand is one of the basic principles fixed in its Article 5.2 In our paper will present some necessary changes as well as radical for the legal system in order to achieve adequate stability and credibility in Europe!
\end{abstract}

Keywords: Ratification, International agreements and guarantee; Consequences; Drawbacks

\section{Introduction}

Firstly the conception of helping character lies in the system of the Convention on Human Rights. This system is implemented and claims to be applied primarily within the judiciary and the jurisdiction of the States Members of European Council. While the European Court of Human Rights has accepted the self-enforcement character of some of the provisions of the Convention and the requirements of the Convention system for positive action by respective countries. Here emerges concrete procedural role of the provisions and the role of the state.

Exactly self-enforcement character has winding two principles, that of autonomy and that of the evolving character and poses as a necessity is direct referral from the state bodies. This should be done for the reason that they should evaluate actions based on an important normative source; for example Articles 166 and 122 of the Constitution which

${ }^{1}$ Refer to C.E.J.I,,A.C.,21 February 1925, series B,no.10

2 Under Article 5 of the Constitution of the Republic of Albania "The Republic of Albania applies international law binding for it" 
should be understood as a resource in itself and increasingly developing concepts for the progress of democracy and consolidation of the Right and the rule of law.

\section{Some Drawbacks in Procedural Reliability}

Of course, in my paper the issue will be considered from two perspectives, each of them selected in order to underline how the benefits and achievements of the Albanian State.

Albanian Constitution within the Albanian reality that precedes lawmaker national doctrine or national jurisdictional system, constitutes achievement expressly firstly is expressed, the legal value of the rate of international normative in the internal normative system of Article 122/1 of the Constitution and secondly is predicted preponderance of ratified international rate law in Article 17 through his second paragraph reaches so far as to establish the European Convention on Human Rights and on its interpretation of the provisions of the constitution. Based on the convention of human rights, the Council of Europe and the member states of it has developed a complete system of defense have in human rights that is based on the full function of Law court.

To this Law court are submitted a significant number and considerable requests from the Member States or individuals against states of the Council of Europe, this is intended to put in right order the violation of rights guaranteed by the Convention and its protocols. In all the decided sanctions that it imposes, its primary effect is the creation of standards for the protection of Human Rights in Europe and progressive growth of these standards.

As long as the convention was created about half a century ago, then legal conscience in Human Rights field it is not what is displayed. Hundreds and dozens of decisions given by the European Court, where Convention norms, rates has been interpreted and its protocols is shown that the Convention achievements are being considered as the most effective and the most dynamic. Through the opinions of the judges in Strasbourg its criteria continue to develop, strengthen and improve the inter-ethnic issues of major importance.

Today are not only solved concrete issues related to the execution of decisions made for violation of the norms of the Convention, but the states are obliged their internal legislation to be adapted to the standards required of it. Then, considering as part of our internal legal system of having priority over the laws, unlike less advanced system other countries have chosen, the European Convention can be directly applied and interpreted from our courts.

In the early years the Court examined about fifty cases, and the number of general cases starting from 1 November 1998 was approximately 1000.This date marks the point when the Court begins to act as a permanent body based on new organizing rules. However the main reason lays elsewhere, during the first period many of the principles and directions of legal provisions for the implementation of the Convention were used for the first time, were defined therefore important starting point for all practice and subsequent judicial proceedings.

The practiced so in precedent case when a decision is taken on an issue, the court is obliged to make a decision on an issue, but is its entrepreneurship to consider the cases of previous decisions in analogous cases and the Court has held rigorously. In cases of significant changes may lead to different decisions by precedents. Previous decisions are taken into account by the court, but in the end those which are not binding for. In particular, Article 50 is now Article 41, according to the amended text of the Convention that contains the changes made by the Protocol 11. Organizing reforms is based on the principle of continuity, without changing the nature of establishing the precedent of previous decisions, but it does not change possibility of attitudes and of the new future focuses. ${ }^{3}$

\section{Results of the Survey}

If we would take the example analysis the exhaust state remedies should be noted that the Commission regularly discusses issues of acceptance, in the absence of which it is not possible that the case or issue to be shown regularly in front of the court .Every state may conduct its point of views (controversy or not) regarding to the exhaustion of remedies and simultaneously will have all the possibilities to correct a decision, while demand is taken into account due to the Commission and the issue of the exhaust state remedies is discussed in width.

By the provisions of Article 122 have a legal-constitutional commitment, in particular the Constitutional Court although my personal self-understanding regarding the New Constitution considering its section 4 can also lead to involvement with this obligation under the other organs that make an assessment judicial of acceptance and

${ }^{3}$ For a European public order. Selected decisions are the European court of human rights". Tirane 2000, Vol. I, pg. 7 
implementation of international law. This is evidenced by the Constitutional Court Section 131 / a, b, c of the Constitution.

Official Journal of international agreements ratified by law is another procedural guarantee, which has the disadvantages. Procedural shortcomings can be encountered in the case of unforeseen agreements. This agreement has not predicting a state body to provide evidence of the official version of the accepted international norm in this last case, especially in solving the incomplete that gives Article 180 of the Constitution to the problem international agreements ratified by Albania before the entry into force of this constitution. If we refer to executive does not find space to do the adaptation to estimate that domestic legislation with international sources.

\section{Results of the Survey}

On the other hand limitation regarding locus standi control reduces the availability of this instance for the correctness of the implementation of international norm.

From what was said above shortcomings and guarantees you just posed, create premises but are not sufficient to achieve proper respect for international norms.

Internal law in accordance to international law

Hard work is done to alter the rates of international law with the right internal and simultaneously to their approaches. Just mentioning the modification of all Albanian legislation deemed adaptation to international norms, as one of the reasons and needs. Consequently other additional normative acts are issued. They have as a goal to respect international law in the interior fields.

This practice is common to all complaints that the Commission treats. According to these circumstances, the state should have the right to refer the issue of exhaust state remedies and to present it in front of the Court with regard to the definition addressing "within which contractual states have agreed to answer for them in front of the Convention "and that the Court should guarantee for treatment ... in the same way as wells as human rights and human liberty ....." which in reality, has no value / for the interests of the state, to exhaust state remedies of respective state ,but the state itself has opportunities to submit to the Commission, as protection of interests competent. Articles 44-45-48 referring to "issues" or "cases" presented to the court by the Commission or by the state for all of jurisdiction which is mentioned as above.

Everyone may ask what does the Convention involves by preciseness of "issue"? The Convention Involves effort is "issue constitutes evidence presentation" and the Commission's opinion" if the evidence presented confirm violation from the state, obligations he has under the Convention "(neni31). Based on this and this report the court has jurisdictional power to interpret and to implement standards of Convection. That means that the court will prove, verify and this constitutes the essence of the issue, it is evident.

The Report passes to the Committee of Ministers (Article 31) and in this case not presented to court, then the ministers take a decision .Advisory Committee of Ministers is the competent body to "whether or not there was a violation of the Convention" (Article 32)

The Court has jurisdictional power to consider "issues relating to the interpretation and application of the Convention"

But in fact there is no difference between the competence of the Committee of Ministers and the jurisdiction of the court .Its then well comprehended that the ministry does not deal with issues of acceptance they decide only whether there is a case of misconduct or not all. But considering this so, is this the same realm or competence as Court's procedure? Ministers certainly interpret and apply the Convention in the same way as the fact that Court does. But the fact that Ministers the bypass issue of acceptance, then it should be taken that even the Court has not this realm or competence. Both parts remain in levels and standards of complementary to each other.

For this reason the opinion that jurisdictional to exhaust state remedies is not the same, there is no reason to believe. In the end, if the Court takes its jurisdiction and acceptance, the result will be the report of the Commission shall not be treated by any responsible body and will not take any definitive decision to the question whether there was a violation or not? Despite the fact that the report firsthand contains members of the Commission's opinion, these violations of the Convention have occurred! This result is injurious to the role and mission of human rights.

The Commission Task is not only that of identification, but that of filtering of legitimate issues, in order to be in compliance with the Convention and its fruitful bases, where even the issues that spark debate should be taken into consideration.

In this regard the adoption of the Constitution of the Republic of Albania, Chapter I-II, Part II when talking about "personal Liberties and Rights" has followed a standard measure of international law of human rights and more specifically in cooperation with the jurisprudence of the Strasbourg Court and the European Convention on Human 
Rights.

Simultaneously law "For Albanian Citizenship" of 1998 amended in 1999 has taken into account several international conventions, the law "for the protection of personal data" and that "for the right to be informed on official documents" law "to foreigners" law of " connection the ombudsman ".

We have received renewed legislation, the essential results; others are expected to come on the design of the Family Code, which in its provisions has enough skills needed for international law. Not to mention the variation and changes in other codes, in order to achieve a harmonized international law bugs in the standard of innovative levels.

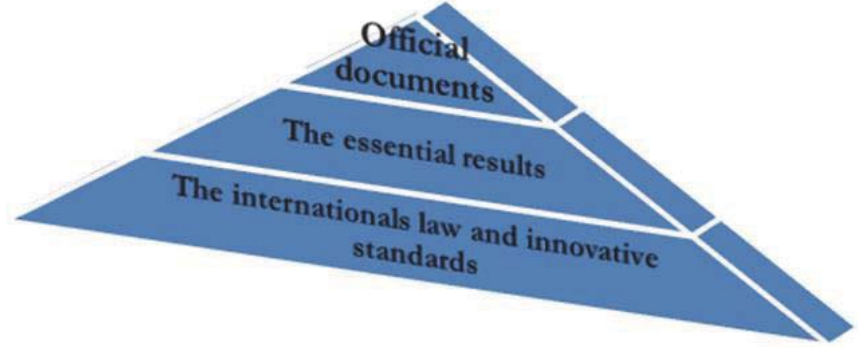

Source: the second international conference APHEG 2014, Dumi A

But although the above was positively pronounced, we have to accept that the material standpoint international norms had its problems. As below s shown:

1) In relation to its practical application in real-jurisdictional processes Albanian

a) The first depends on the varying conceptual time of the past. A source of law, which has been in force until 2000

b) The second is due to ignorance of the state administration and special sectors, but especially in the judiciary, the international rate and the manner of implementation in internal normative system.

Because of the change in procedures, there is a gap. If we take all for granted, then everything goes pro application of international law. But if we refer to the education of our magistrates, on the possibility of self-enforcement may result in the name of international law enforcement. Obviously if we take measures in terms of a positive nature, which cannot be only legislation in line with international acts .We criminal procedure code, for example, is not anticipated that the prosecutor has the legal duty to realize prosecution.

What happens to violations of international norms that are accepted to have drittwirkung effect (horizontal effect) individual relationship? ${ }^{4}$ Penal Code procedure uses a hierarchy of changing the source of international law from which it uses its international law through 1969 Vienna Convention. ${ }^{5}$

c) Thirdly the incorrect interpretation of international acts due to ignorance of the implementation instruments on acts with innovative jurisdictional nature. For example ... the execution office should have an executive character and not court decisions.

d) Not published of international acts in the Official Journal brings procedural hurdles, by this we can say that the difficulty existed not only in procedural nature character. There is evidently a gap and a failure to bring the international acts as it should properly, as far as Law translations coming from English or French are not accurate, because sometime they are expressed by legal term of time and other times with the same law terms for the same term.

And the literal or textual interpretation, derived from foreign languages English and French is one of the essential interpretation during court sentences. Without letting apart here the fact that the main rule of the Conventional of Human Rights is literal and then it is contextual depending on the data or situational circumstances.

I would have the courage that these jurisdictional aspects specifically affect law principles of International Right in the proportion to the general right. There are some clashes materially and procedurally that the proportion of international law to the extent of the Albanian legislation undergoes in some oscillations.

\footnotetext{
4 "For an European public order. Selected decisions are the European court of human rights". Tirane 2000,Vol I , p.p 22

5 "For an European public order. Selected decisions are the European court of human rights". Tirane 2000,Vol I, p.p 22 


\section{Conclusions}

As far as Albanian legislation obliges government bodies to implement the European Convention of Human Rights and this more for the fact that the Convention itself constitutes a normative source within the legal system of the Republic of Albania as mentioned above .As mentioned in international convention of the Human Rights is part of the category of international treatments and under the Constitution get enforce in the Republic of Albania. It is more than sufficient having realized generally known rules of international law relating to treaties -ratification or completion of procedures analogous to it, by the respective state. This is a general content of international law pacta sunt servanda, general principle foreseen by the Treaty of Vienna. ${ }^{6}$

Rep. Albania has met termination procedures of the European Convention of Human Rights, this treaty with international special character with its signature on 13 July 1996, with its ratification through nr.8137 law of 31 July 1996.Depending on good reason, and with a certain way-with constitutional provisions, the Republic of Albania provides not only clear but also positioning additional clarifications regarding international agreements and therefore also their application within the country.

These features and characteristics are laid down in our paper, not only to achieve progress justified by an article in another, but to reiterate that the consolidation of democracy in Albania Rep is open so as to complete against the gates Europe and the European Convention on Human Rights. As the results are open ahead and the difficulties are evident we have guessed that when achieving one goal we understand the necessity of the next stage in progress!

European Court is responsible for ensuring strict supervision and implementation of the Convention by the States Parties .It performs this task by reviewing and making decisions for special cases brought before it on the basis of individual applications submitted by individuals, groups of individuals or organizations even non-governmental ones .Except of this is possible for a Contracting State to submit a request to express violation of the Convention by another State member. Court and the European Court precedent have substantially contributed to the interpretation of the rights expressed by the European Convention.

European Convention ratified by the Albanian state, and recognition of the jurisdiction of the European Court gives possibilities to all persons (citizens or not) submitting a request to the European Court of Human Rights that they think they rights are violated by law or Albanian state. When a state provides that the situation examined from the Council of Europe is right and that it will be adjusted until some changes in legislation or law case, usually are suggested necessary changes.

It is exactly this kind of responsibility for verification of each application legislature and decision to regulate any inconsistency between the Council of Europe standards with interior law or law case in the respective decision of the Court.

\section{References}

"The Constitution of the Republic of Albania " Tirana 1998, pp 78-91

"Guides stones-jurisprudence of the European Court of Human Rights" Tirana 2000.Vol 1 p. p 198

"Guides stones-jurisprudence of the European Court of Human Rights" Tirana 2000.Vol 1fq 198

"Law court and the Convention of the Rights of Man "European University Centre of Warsaw vol 2 , 2001 pp 19-21

"For a European public order; Selected decisions are the European court of human Rights Tirana2000,Vol I ,pp 7

"For a European public order". Selected decisions are the European court of human rights". Tirana 2000,Vol I, pp 289

"For a European public order". Selected decisions are the European court of human rights". Tirana 2000 I, pp 22

"Vienna Convention on the Law of Treaties" VLC Vienna, Austria 1980 pp 89-91 
